\author{
ANNA IRENA SZYMAŃSKA \\ Uniwersytet Ekonomiczny w Krakowie, Polska \\ Cracow University of Economics, Poland
}

\title{
Modele biznesu w sharing economy w kontekście grup społecznościowych działajacych w cyberprzestrzeni
}

\section{Sharing economy business models in the context of social groups operating in cyberspace}

\begin{abstract}
Streszczenie: Idea sharing economy wiąże się z udostępnianiem dóbr, informacji bądź umiejętności przez określone osoby innym osobom na zasadach non profit, profit lub barteru przy wykorzystaniu przystosowanych do tego celu wirtualnych narzędzi. Przedsięwzięcia podejmowane w tym obszarze charakteryzują się dużym zróżnicowaniem, które ma swoje odzwierciedlenie w różnych sposobach klasyfikacji modeli biznesu sharing economy. Przyjmując jako kryterium klasyfikacji owych modeli obszary współdzielenia, można wyszczególnić cztery ich kategorie: recyrkulacja towarów, zwiększenie wykorzystania aktywów trwałych, wymiana usług oraz udostępnienie aktywów wytwórczych. Wspomniane kryterium i oparta na nim klasyfikacja stały się podstawą dalszych analiz i badań empirycznych. Celem niniejszego artykułu była analiza specyfiki funkcjonowania grup wirtualnych działających w ramach portali społecznościowych umożliwiająca potwierdzenie postawionej na wstępie tezy, zgodnie z którą: wirtualne grupy, pełniąc podobne funkcje jak platformy internetowe sharing economy, działają w oparciu o określone modele biznesowe, z tą różnicą, że nie pobierają opłat za dostęp i umożliwianie tworzenia się relacji między partnerami transakcji. W artykule podjęto również próbę identyfikacji kluczowych cech modeli biznesu sharing economy charakterystycznych dla grup społecznościowych działających w cyberprzestrzeni. W badaniach zastosowano metodę triangulacji (analiza literatury przedmiotu, obserwacja bierna i obserwacja uczestnicząca ukryta).
\end{abstract}

\footnotetext{
Abstract: The idea of sharing economy is associated with the provision of goods, information or skills by some people to other people on a non-profit, profit or barter basis using virtual tools adapted for this purpose. Actions taken in the area of sharing economy are highly diversified, which is reflected in different ways of classifying sharing economy business models. Assuming the area of sharing as the model classification criterion, four categories can be distinguished: recirculation of goods, increasing the use of fixed assets, exchange of services and making production assets available. The mentioned criterion and the classification based on it became the basis for further analyses and empirical research. The aim of this article was to analyse the functioning of virtual groups that operate within social networking sites. This made it possible to confirm the following thesis: virtual groups, performing similar functions to sharing economy internet platforms, operate on the basis of specific business models, with the difference that they do not charge for access and
} 
for enabling relationships between transaction partners. The article also attempts to identify the key features of sharing economy business models characteristic of social groups operating in cyberspace. The research used the triangulation method (literature analysis, passive observation and covert participant observation).

Słowa kluczowe: ekonomia współdzielenia; grupy internetowe; grupy społecznościowe; modele biznesu; obserwacja bierna; obserwacja uczestnicząca ukryta; platformy internetowe; sharing economy

Keywords: business models; covert participant observation; internet groups; internet platforms; passive observation; sharing economy; social groups

Otrzymano: 6 kwietnia 2021

Received: 6 April 2021

Zaakceptowano: 26 czerwca 2021

Accepted: 26 June 2021

Sugerowana cytacja / Suggested citation:

Szymańska, A.I. (2021). Modele biznesu w sharing economy w kontekście grup społecznościowych działających w cyberprzestrzeni. Prace Komisji Geografii Przemysłu Polskiego Towarzystwa Geograficznego, 35(3), 62-75, doi: https://doi.org/10.24917/20801653.353.4

\section{WSTĘP}

Obserwowany powszechnie postęp techniczny, technologiczny i informacyjny w znaczącym stopniu poszerzył granice możliwości przedsiębiorstw w zakresie dostarczania wartości klientom. We współczesnym, silnie konkurencyjnym otoczeniu, przedsiębiorstwa stoją przed wyzwaniem radzenia sobie z dużą ilością danych, koniecznością podejmowania szybkich decyzji i uelastycznianiem procesów produkcyjnych. Przemianom tym towarzyszy powstawanie kolejnych koncepcji modeli biznesu, które umożliwiają opisanie, scharakteryzowanie i analizę obszarów funkcjonowania oraz otoczenia określonego podmiotu gospodarczego, a także wyszczególnienie potencjalnych źródeł osiągania przewagi konkurencyjnej (Falencikowski, 2012).

Nowe usługi w środowisku nowych technologii mogą prowadzić do kształtowania się modeli e-biznesu, charakteryzujących się innowacyjnością, elastycznością, otwartością i generowaniem wartości dla interesariuszy. Uwagę zwraca ponadto innowacyjne podejście do finansowania, serwisy społecznościowe, angażujące internautów we współtworzenie dóbr i usług, usługi mobilne, cloud computing, a także dwu- lub wielostronne modele biznesowe. Biznes elektroniczny (electronic business, e-business) najczęściej definiowany jest jako „wykorzystanie Internetu do powiązania (łączenia) oraz ułatwiania prowadzenia (wykonywania) przedsięwzięć biznesowych, handlu elektronicznego, komunikacji i współpracy wewnątrz firmy oraz z jej klientami, dostawcami i innymi partnerami biznesowymi" (Nojszewski, 2006: 1). Przedsięwzięcia e-biznesowe realizowane są zazwyczaj z wykorzystaniem Internetu, intranetu, ekstranetu i innych rodzajów sieci do wspierania realizowanych procesów gospodarczych (Combe, 2006).

Obserwacja aktualnych trendów rozwoju najnowocześniejszych serwisów wskazuje na ewoluowanie modeli e-biznesowych w kierunku wirtualnych rynków czy sieci powiązań, w ramach których producenci i konsumenci poszukują i łączą się dynamicznie, krótkoterminowo, jedynie na czas realizacji transakcji biznesowej lub w celu osiągnięcia innych zamierzonych celów biznesowych. Zwiększa się również różnorodność i skala podejmowanych działań gospodarczych w cyberprzestrzeni, prowadząc w efekcie do znacznego skomplikowania modeli, według których funkcjonują przedsiębiorstwa. 
Szczególną odmianą modeli e-biznesu są modele związane z ekonomią współdzielenia (sharing economy). Zazwyczaj są to platformy oparte na współpracy (collaboration platforms) pobierające opłatę za dostęp oraz korzystanie z narzędzi wspierania relacji między partnerami. Idea sharing economy polega na udostępnianiu dóbr, informacji bądź umiejętności przez określone osoby innym osobom na zasadach non profit, profit lub barteru z wykorzystaniem przystosowanych do tego wirtualnych narzędzi ${ }^{1}$ (Płaziak, Szymańska 2019; Szymańska, 2017, 2018, 2020). Przedsięwzięcia postrzegane jako działania w obszarze sharing economy charakteryzują się dużym zróżnicowaniem, co jest rezultatem niejednoznaczności w definiowaniu sharingu. Z drugiej strony dostrzega się jednak pewne prawidłowości i podobieństwa w ramach podejmowanych aktywności.

Zasadniczym celem artykułu była analiza specyfiki funkcjonowania grup wirtualnych działających w ramach portali społecznościowych, a w rezultacie potwierdzenie postawionej tezy, zgodnie z którą wirtualne grupy pełniąc podobne funkcje jak platformy internetowe sharing economy działają w oparciu o określone modele biznesowe, z tą różnicą, że nie pobierają opłat za dostęp i umożliwianie tworzenia się relacji między partnerami transakcji. Ponadto podjęto również próbę identyfikacji kluczowych cech modeli biznesu sharing economy grup działających w cyberprzestrzeni. Należy tu podkreślić, że prezentowane badania mają charakter nowatorski. Opisywane w literaturze przedmiotu badania zazwyczaj koncentrują się jedynie na funkcjonowaniu platform internetowych w obszarze sharingu nierozpatrując grup wirtualnych, które mogą przecież pełnić podobne funkcje.

\section{MODELE BIZNESU W OBSZARZE SHARING ECONOMY}

Modele biznesu stanowią konfigurację procesów biznesowych łączących i rozwijających zasoby, ukształtowane w formie architektury społecznej („miękkiej”) i technicznej przedsiębiorstwa („twardej”) (rycina 1).

Rycina 1. Model biznesowy przedsiębiorstwa

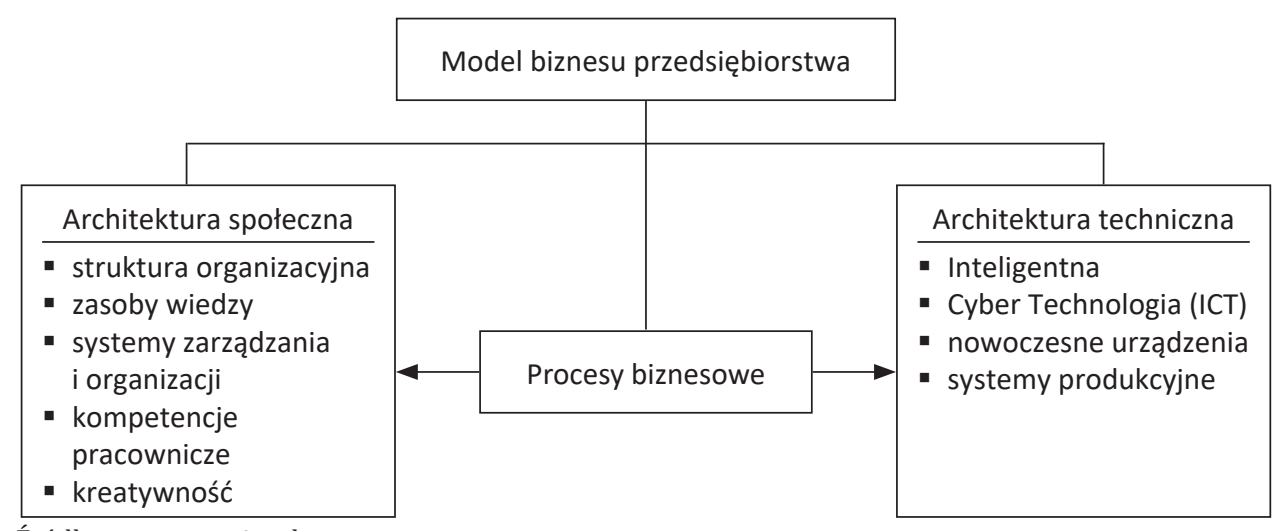

Źródło: opracowanie własne

${ }^{1}$ Zgodnie z definicją Komisji Europejskiej sharing economy to „łączenie osób fizycznych i prawnych za pomocą platform internetowych, aby umożliwić im świadczenie usług lub wspólne korzystanie z aktywów, zasobów, czasu, umiejętności lub kapitału, nierzadko w ograniczonym czasie i bez przekazywania praw własności" (PwC Polska, 2016). 
Powstają jako reakcja podmiotów gospodarczych na różnorodne wymagania stawiane im przez otoczenie, co więcej, definiują sposób zarabiania pieniędzy przez poszczególne podmioty (Johnson, 2010). W literaturze przedmiotu można odnaleźć wiele definicji modeli biznesowych (w tym też e-biznesowych) i wiele propozycji ich klasyfikacji. Często stosowane kryteria ich podziału to m.in.: cel biznesowy, poziom zaawansowania technologicznego, sposób konfiguracji dobra i usługi, czy źródła generowania dochodów (Poniatowska-Jaksch, 2013). Istotą modelu zazwyczaj jest wartość, jaką otrzymują klienci, jak również wartość samego przedsiębiorstwa. Budowane są w oparciu o różne kryteria, np. relacje podmiotów rynkowych, czy też źródła budowania przewagi konkurencyjnej. Zazwyczaj założenia panujące $w$ danej branży traktowane są jako wyznaczniki dla określonego modelu. Wraz ze zmianami w funkcjonowaniu branży obserwuje się zmiany w modelach biznesowych, które mogą dokonać się przez:

- renowację istniejącego, obecnego modelu biznesu,

- zbudowanie nowego modelu biznesu (lub modeli) „obok” już istniejących i stopniowe przechodzenie od jednego do drugiego (Gajdzik, Grabowska, 2018).

W modelach biznesu dużą wagę przywiązuje się do kreowania, dostarczania i przechwytywania wartości oraz tworzenia relacji z klientami (Osterwalder, Pigmeur, 2012). Modele te informują, w jaki sposób organizacja buduje wartość dla klienta, tworząc jednocześnie wartość dla samej siebie (Johnson, 2013). Na problematyce wartości opiera się również koncepcja firmy-idei, zgodnie z którą celem organizacji nie jest lepsze zaspokajanie potrzeb klienta, a jego upodmiotowienie i włączenie w społeczny proces wytwarzania wartości firmy. W podejściu tym wartości pozaekonomiczne służą kreacji wartości ekonomicznej (Hausner, Zmyślony, 2015). Podobne współzależności dostrzegalne są także w modelach biznesu sharing economy, gdzie jednym z elementów sukcesu jest właśnie tworzenie wartości dla klienta, rozpatrywane w ujęciu ekonomicznym, społecznym, praktycznym i środowiskowym (Poniatowska-Jaksch, 2016; Rude, 2016). Bez wątpienia głównym stymulatorem procesu kreacji wartości oraz tworzenia nowych relacji z klientami jest dynamiczny rozwój sieci technologicznych (Internet) i społecznych (sieci społeczne). Sieci te tworzą współczesne środowisko biznesowe, w ramach którego ich użytkownicy tworzą społeczności online, oparte na wspólnych interesach, często umożliwiające wymianę bądź dostęp do określonych dóbr bez konieczności nabywania ich na własność.

Rozpatrując modele biznesu sharing economy nie sposób nie wspomnieć o klasyfikacji modeli zaproponowanej przez Weilla i Vitale, której podstawą są relacje występujące między firmą a konsumentami, klientami, sojusznikami i dostawcami, a także bezpośrednio powiązane z nimi przepływy produktów, informacji, pieniędzy oraz korzyści dla współuczestników modelu (Weill, Vitale, 2001). Znajduje tu zastosowanie model ukierunkowany na klienta oraz model pośrednika. Model ukierunkowany na klienta cechuje występowanie bezpośredniej komunikacji między kupującym a sprzedającym (klientem może być zarówno osoba fizyczna, jak i przedsiębiorstwo). W przypadku modelu pośrednika są to portale, agenci, aukcje itp., ułatwiające nawiązanie relacji między sprzedającymi i kupującymi.

Modele biznesu sharing economy można również podzielić ze względu na: obszar współdzielenia, orientację rynkową (non profit lub for profit), czy skalę działania (lokalna, międzynarodowa). Klasyfikacja ze względu na obszar współdzielenia odnosi się zwykle do podziału na aktywa materialne/rzeczowe (wynajem pokoi, pojazdów) oraz aktywa niematerialne (crowdfunding, banki czasu). Przyjmując nieco bardziej 
szczegółowe podejście do obszarów współdzielenia można wyszczególnić takie cztery kategorie jak recyrkulacja towarów (aukcje internetowe, wymiana rzeczy - zabawek, książek, sprzętu sportowego), zwiększenie wykorzystania aktywów trwałych (wynajem pokoi, odpłatne użyczenie sprzętu domowego użytku, wynajem pojazdów), wymiana usług (banki czasu - nauka języków obcych czy gry na instrumentach, doradztwo podatkowe) oraz udostępnienie aktywów wytwórczych (udostępnianie narzędzi i miejsc do pracy - coworking) (Poniatowska-Jaksch, 2016; Schor, 2014).

\section{OBSERWACJA UCZESTNICZĄCA W BADANIU ZACHOWAŃ INTERNAUTÓW}

Obserwacja zachowań respondentów w ich naturalnym środowisku przebywania należy do grupy metod z zakresu badań etnograficznych. W badaniach empirycznych stanowiących podstawę weryfikacji postawionej na wstępie tezy zastosowano dwie metody jakościowe: obserwację bierną oraz obserwację uczestniczącą ukrytą ${ }^{2}$. Obserwacja bierna opiera się na uczestnictwie biernym lub peryferyjnym, w ramach którego badacz jedynie przygląda się aktywności użytkowników, nie wchodzi natomiast w interakcje i nie wpływa swoją obecnością na ich zachowania. W przypadku obserwacji czynnej badacz sam staje się użytkownikiem usług internetowych (czat, portal, sklep internetowy, czy medium społecznościowe tj.: blog, vlog, mikroblog, wirtualny świat tzw. Second Life, serwis społecznościowy, jak np. Facebook, Instagram) i staje się pełnoprawnym członkiem danej społeczności a tym samym wtapia się w środowisko, które chce poznać.

W literaturze przedmiotu występuje wiele definicji obserwacji uczestniczącej, z których każda podkreśla wybrane aspekty tej techniki badawczej. Według Schwartza „obserwacja uczestnicząca jest procesem badawczym, w którym obserwator przebywa w środowisku społecznym dla celów badań naukowych. Obserwator jest w bezpośrednich, bliskich stosunkach z obserwowanymi i współuczestnictwo w ich naturalnym życiu dostarcza mu materiałów badawczych" (Doktór, 1964: 43). Technika obserwacji uczestniczącej jest dość często wykorzystywana na gruncie nauk społecznych i wiązana jest z podejściem naturalistycznym, zgodnie z którym „jeśli to tylko możliwe, świat społeczny powinien być badany w jego 'naturalnym' stanie, niezakłóconym przez badacza" (Hammersley, Atkinson, 2000: 16). Prowadzenie badań w środowisku naturalnym zwiększa prawdopodobieństwo zrozumienia badanej rzeczywistości, umożliwia zbliżenie się do doświadczeń życiowych uczestników w większym stopniu, niż przy zastosowaniu obserwacji biernej (Chomczyński, 2006; Prus, Grills, 2003: 24). Idea obserwacji uczestniczącej wywodzi się z badań etnograficznych i antropologicznych, w ramach których koncentrowano się na poznaniu zwyczajów kulturowych plemion (Babbie 2003: 309; Chomczyński, 2006; Shaughnessy, Zechmeister, Zechmeister, 2002: 106).

Odmianą obserwacji uczestniczącej jest obserwacja uczestnicząca ukryta, nazywana również zamaskowaną obserwacją uczestniczącą (Shaughnessy, Zechmeister, Zechmeister, 2002: 106). Badacz wykorzystujący tę technikę w trakcie badania ukrywa swoją tożsamość przed wszystkimi lub niektórymi podmiotami obserwacji (Hammersley, Atkinson, 2000: 81, 270). W literaturze podkreśla się jej relatywnie szerokie

${ }^{2}$ Trzecim wariantem jest obserwacja pośrednia, podczas której badacz jest aktywny, podejmuje działania w obrębie grupy, ale nie angażuje się w pełni, nie wpływa na system wartości grupy, realizowane cele. 
stosowanie w badaniach poświęconych funkcjonowaniu różnego rodzaju mniej lub bardziej formalnych grup (Chomczyński, 2006). Uzasadnieniem stosowania tej metody może być powszechne wśród badaczy przekonanie, że ujawnienie celu badań zniweczyłoby wszelkie próby poznania prawdy. Zakłada się, że osoby mające świadomość tego, iż są obserwowane nie będą zachowywały się swobodnie, co w efekcie wpłynie na zniekształcenie wyników badania (Chomczyński, 2006; Farrington, Robinson, 1999: 180; Hammersley, Atkinson, 2000: 270; Konecki, 2000: 149; Shaughnessy, Zechmeister, Zechmeister, 2002: 106).

Wykorzystanie obserwacji (zarówno biernej, jak i uczestniczącej) jako techniki badawczej wydaje się być właściwym wyborem w badaniach społeczności funkcjonujących w świecie wirtualnym, umożliwiającym dogłębne ich poznanie na wielu płaszczyznach. Dla przykładu, badania prowadzone w ramach takich nauk społecznych, jak etnografia, geografia i socjologia, umożliwiają pogłębienie wiedzy w zakresie powstawania, funkcjonowania, czy rozwoju grup internetowych. Mogą dotyczyć m.in. zagadnień tożsamości społeczności, czynników i stopnia integracji oraz ewolucji. Zastosowanie obserwacji w badaniach marketingowych może być przydatne m.in. w przewidywaniu przyszłych trendów, postrzeganiu marki, podejmowaniu działań w zakresie kreowania, wdrażania i rozwoju nowych produktów, komunikacji marketingowej, monitorowania kanałów między konsumentami w celu identyfikacji potencjalnego popytu na określone produkty itp. (Cichocki, Jędrkiewicz, Zydel, 2012; Płaziak, 2020).

Wyróżnia się pięć elementów/kryteriów obserwacji, które powinny zostać uwzględnione w procesie badawczym przez obserwatora uczestniczącego, zanurzonego w badanej społeczności: organizacja czasu i przestrzeni, obiekty, aktorzy społeczni, interakcje, wydarzenia (Ciesielska, Wolanik Boström, Öhlander, 2012; Płaziak, 2020) - tabela1.

Uwzględnienie w prowadzonych badaniach omówionych powyżej elementów/ kryteriów obserwacji, warunkuje prawidłowe i kompleksowe przeprowadzenie badania pozwalając na szerokie spektrum poznania badanej społeczności, a jednocześnie zawężając obszar, czas i uczestników badania.

Tabela 1. Charakterystyka kluczowych elementów/kryteriów obserwacji w procesie badawczym cyberprzestrzeni

\begin{tabular}{|c|l|l|}
\hline Lp. & $\begin{array}{l}\text { elementy/kryteria } \\
\text { obserwacji }\end{array}$ & \multicolumn{1}{|c|}{ Charakterystyka w odniesieniu do cyberprzestrzeni } \\
\hline 1. & $\begin{array}{l}\text { Organizacja czasu } \\
\text { i przestrzeni }\end{array}$ & $\begin{array}{l}\text { Spotkania odbywają się w cyberprzestrzeni, brak ograniczenia czasowego, } \\
\text { w dyskusję można włączyć się w dowolnej chwili, wyjątkiem może być sytu- } \\
\text { acja, gdy wyznaczono terminy wideokonferencji, spotkań na czacie lub relacji } \\
\text { online, zazwyczaj istnieje możliwość odtworzenia i skomentowania w dogod- } \\
\text { nym czasie. }\end{array}$ \\
\hline 2. & $\begin{array}{l}\text { Przez lokalizację należy tu rozumieć adresy sieciowe forów, stron interneto- } \\
\text { wych, blogów, grup utworzonych w ramach określonych serwisów społeczno- } \\
\text { lokalizacja } \\
\text { i dostępność } \\
\text { sciowych (np. Facebook, Instagram, Twiter), skupiających w cyberprzestrzeni } \\
\text { osoby, które łączą wspólne zainteresowania, pasje, reprezentowane w danej } \\
\text { dziedzinie poglądy, względy ekonomiczne, czy konkretne terytorium (np. } \\
\text { miasto, dzielnica, osiedle) i związane z nim wydarzenia, problemy, wspomnie- } \\
\text { nia itp. } \\
\text { W procesie badawczym wykorzystywane jest konkretne medium interneto- } \\
\text { we, które charakteryzują takie elementy, jak: dostępność (otwarta lub ograni- } \\
\text { czona poprzez login i hasło), struktura i szata graficzna, czy stopień skompli- } \\
\text { kowania w obsłudze i użytkowaniu. }\end{array}$ \\
\hline
\end{tabular}




\begin{tabular}{|c|l|l|}
\hline 3. & Aktorzy społeczni & $\begin{array}{l}\text { Ograniczona możliwość wglądu w zachowania (mimika twarzy, język ciała, } \\
\text { gesty) poszczególnych członków społeczności ze względu na utrudniony lub } \\
\text { niemożliwy kontakt wzrokowy - zazwyczaj w ramach społeczności wirtu- } \\
\text { alnych brak jest możliwości prowadzenia rozmów z wykorzystaniem wizji. } \\
\text { Konieczne wnioskowanie na podstawie tekstów, symboli, znaków umieszcza- } \\
\text { nych przez poszczególnych członków społeczności, wskazane jest tu ograni- } \\
\text { czone zaufanie co do prawdziwości wypowiedzi internautów, konieczne we- } \\
\text { ryfikowanie z wypowiedziami innych członków. }\end{array}$ \\
\hline 4. & $\begin{array}{l}\text { Najczęściej brak możliwości rejestracji niektórych werbalnych i niewerbal- } \\
\text { nych zachowań ze względu na ograniczony do minimum kontakt „face to face” } \\
\text { (lub wręcz całkowity jego brak). } \\
\text { Identyfikacja emocji, intencji, opinii, poziomu zaangażowania poszczególnych } \\
\text { członków badanej społeczności w konkretną sprawę lub problem, prowa- } \\
\text { dzona na podstawie użytych zwrotów, wyrazów, znaków interpunkcyjnych, } \\
\text { emotikonów itp., konieczność tzw. „czytania między wierszami”. }\end{array}$ \\
\hline 5. & Wydarzenia & $\begin{array}{l}\text { Wydarzenia odbywają się w cyberprzestrzeni, będą to więc zazwyczaj opi- } \\
\text { nie czy wymiany poglądów. Nawet w sytuacji, gdy będzie to protest czy akcja } \\
\text { charytatywna, będzie się odbywać w inny sposób niż taka aktywność w prze- } \\
\text { strzeni realnej. W sieci dostęp do informacji częstokroć jest łatwiejszy i nie- } \\
\text { ograniczony czasowo. }\end{array}$ \\
\hline
\end{tabular}

Źródło: opracowanie własne na postawie Płaziak (2020)

\section{METODYKA PROWADZONYCH BADAŃ}

W okresie od lutego do czerwca 2020 roku przeprowadzono badania bezpośrednie, w ramach których obserwacji poddano 90 grup internetowych utworzonych na platformach Facebook i Instagram, działających w obszarze sharing economy i zrzeszających głównie młodych ludzi. W badaniach zastosowano metodę triangulacji obejmującą: analizę literatury przedmiotu z zakresu funkcjonowania wirtualnych społeczności w obszarze ekonomii współdzielenia, jak również obserwację bierną i obserwację uczestniczącą ukrytą. Analizy uzyskanych wyników dokonano w oparciu o autorski warsztat badawczy opracowany na podstawie literatury metodologicznej traktującej o badaniach jakościowych.

Należy tu zwrócić uwagę na fakt, iż platformy internetowe, takie jak Facebook czy Instagram, określane również mianem serwisów społecznościowych, służą zwyczajnej wymianie informacji. W ramach świadczeń wykonywanych przez administratorów tego rodzaju platform nie dostrzega się specyficznych cech, które wskazywałyby na związek z ekonomią współdzielenia. Mogą być one jednak wykorzystywane przez użytkowników do współdziałania w celu realizacji wartości uznawanych za konstytutywne dla ekonomii współdzielenia. Ponadto coraz częściej obserwuje się, iż administratorzy platform z obszaru sharingu tworzą profile w ramach serwisów społecznościowych. Stanowią one wówczas uzupełnienie głównej działalności realizując funkcję informacyjną i komunikacyjną z użytkownikami danej platformy. Grupy wirtualne zakładane są także przez osoby korzystające $\mathrm{z}$ oferty platform, stanowiąc przestrzeń do wymiany wiedzy i doświadczeń związanych użytkowaniem platformy. Owa różnorodność intencji tworzenia grup wirtualnych, prowadząca do realizacji działań w obszarze sharing economy, stanowiła przyczynek do podjęcia badań empirycznych.

Zasadniczym celem badań była analiza specyfiki funkcjonowania grup wirtualnych działających w ramach portali społecznościowych umożliwiająca potwierdzenie tezy, zgodnie z którą wirtualne grupy pełniąc podobne funkcje jak platformy internetowe sharing economy działają w oparciu o określone modele biznesowe, $\mathrm{z}$ tą różnicą, że nie 
pobierają opłat za dostęp i umożliwianie tworzenia się relacji między partnerami transakcji. Realizują podobne zadania, mimo iż z prawnego punktu widzenia nie stanowią działalności gospodarczej. Ponadto podjęto próbę identyfikacji kluczowych cech modeli biznesu sharing economy grup działających w cyberprzestrzeni.

Punktem wyjścia przy przeprowadzaniu obserwacji o charakterze jakościowym było przeanalizowanie poszczególnych stadiów przygotowania i przeprowadzenia obserwacji. Procedura badawcza obejmowała następujące etapy: opracowanie koncepcji obserwacji, dokonanie wyboru miejsca prowadzenia obserwacji, zaprojektowanie narzędzia badawczego, przeprowadzenie szkolenia badaczy wspierających, pozyskanie zgody na przeprowadzenie obserwacji w badanej przestrzeni, realizacja obserwacji wstępnych, przeprowadzenie badań właściwych i analiza uzyskanych wyników badań (tabela 2).

Tabela 2. Etapy przeprowadzenia badań empirycznych z wykorzystaniem obserwacji jako metody badawczej

\begin{tabular}{|c|c|c|}
\hline Lp. & Etapy badania & Charakterystyka \\
\hline 1. & $\begin{array}{l}\text { Opracowanie } \\
\text { koncepcji } \\
\text { obserwacji }\end{array}$ & $\begin{array}{l}\text { Analiza literatury przedmiotu, opracowanie koncepcji badań, sformułowanie } \\
\text { celu i pytań badawczych, wyszczególnienie obszarów badawczych mieszczą- } \\
\text { cych się w przestrzeni sharing economy, w ramach których prowadzono bada- } \\
\text { nia (transport, nieruchomości, gastronomia, finanse, wymiana dóbr i wiedzy, } \\
\text { banki czasu/umiejętności). }\end{array}$ \\
\hline 2. & $\begin{array}{l}\text { Wybór miejsca } \\
\text { prowadzenia } \\
\text { obserwacji }\end{array}$ & $\begin{array}{l}\text { Miejsce prowadzenia obserwacji stanowiła przestrzeń wirtualna - portale } \\
\text { społecznościowe (Facebook, Instagram). }\end{array}$ \\
\hline 3. & $\begin{array}{l}\text { Zaprojektowanie } \\
\text { narzędzia } \\
\text { badawczego }\end{array}$ & $\begin{array}{l}\text { Ujednolicony arkusz umożliwiający ustrukturalizowaną charakterystykę } \\
\text { badanych grup wirtualnych, służący do pomiaru obserwowanych zjawisk. } \\
\text { Zawierał szczegółowe polecenia dotyczące zarówno obserwacji biernej, jak } \\
\text { również obserwacji uczestniczącej ukrytej. }\end{array}$ \\
\hline 4. & $\begin{array}{l}\text { Przeprowadzenie } \\
\text { szkolenia badaczy } \\
\text { wspierających }\end{array}$ & $\begin{array}{l}\text { Funkcję badaczy wspierających pełnili wybrani studenci uczelni ekonomicz- } \\
\text { nej, którzy zostali przeszkoleni, a także wyposażeni w ujednolicony arkusz } \\
\text { badawczy oraz szczegółową procedurę dot. prawidłowego prowadzenia ob- } \\
\text { serwacji biernej i uczestniczącej ukrytej w środowisku wirtualnym. }\end{array}$ \\
\hline 5. & $\begin{array}{l}\text { Pozyskanie } \\
\text { zgody na } \\
\text { przeprowadzenie } \\
\text { obserwacji } \\
\text { w badanej } \\
\text { przestrzeni }\end{array}$ & $\begin{array}{l}\text { Procedura pozyskania zgody na przeprowadzenie obserwacji obejmowała } \\
\text { trzy etapy: 1) zgłoszenie chęci stania się członkiem wybranej grupy interne- } \\
\text { towej; 2) akceptacja regulaminu grupy przez badacza; 3) przyjęcie go przez } \\
\text { administratora do grupy wirtualnej poddanej badaniu. }\end{array}$ \\
\hline 6. & $\begin{array}{l}\text { Realizacja } \\
\text { obserwacji } \\
\text { wstępnych }\end{array}$ & $\begin{array}{l}\text { Przeprowadzenie obserwacji kilku wybranych grup internetowych, mające na } \\
\text { celu weryfikację poprawności narzędzia badawczego. }\end{array}$ \\
\hline 7. & $\begin{array}{l}\text { Przeprowadzenie } \\
\text { badań właściwych } \\
\text { - obserwacji } \\
\text { biernej, } \\
\text { a następnie } \\
\text { obserwacji } \\
\text { uczestniczącej } \\
\text { ukrytej }\end{array}$ & $\begin{array}{l}\text { Zogniskowana obserwacja bierna i uczestnicząca ukryta (zawężenie badań } \\
\text { do wybranych grup w oparciu o przyjęte kryteria) - składająca się z nastę- } \\
\text { pujących etapów: wyszukanie grup wirtualnych w ramach wyznaczonych } \\
\text { obszarów, zapisanie się badacza do wybranych grup, szczegółowa analiza } \\
\text { informacji dot. wyszukanych grup (rok założenia, liczba członków, poziom } \\
\text { aktywności członków - liczba postów umieszczanych dziennie, tematyka po- } \\
\text { stów), wybór grup o największym natężeniu aktywności, mieszczących się } \\
\text { w wybranej tematyce, obserwacja bierna wybranych grup, obserwacja czynna } \\
\text { grup, polegająca na umieszczeniu min. } 3 \text { postów w ramach obserwowanych } \\
\text { grup i stymulowanie dyskusji przez ok. tydzień, ponadto komentowanie wy- } \\
\text { powiedzi innych członków grup. }\end{array}$ \\
\hline
\end{tabular}

Źródło: opracowanie własne 
Kluczowym punktem na etapie opracowania koncepcji planowanych badań empirycznych było wyszczególnienie głównych obszarów badawczych w przestrzeni sharing economy, które miały zostać objęte dalszymi badaniami. W toku pogłębionej analizy literatury przedmiotu wyszczególniono takie obszary jak: transport, nieruchomości, gastronomia, finanse, wymiana dóbr i wiedzy, banki czasu/umiejętności. Badania empiryczne rozpoczęto od wyszukania grup wirtualnych funkcjonujących w ramach takich portali społecznościowych jak Facebook i Instagram i mieszczących się tematycznie w wyszczególnionych obszarach badawczych. Wspomniane grupy wyszukiwane były przede wszystkim poprzez stosowanie słów kluczowych adekwatnych dla poszczególnych obszarów badawczych. Na tym etapie wyszukano łącznie 455 grup wirtualnych, zarówno polsko-, jak i angielskojęzycznych. Szczegółowa analiza informacji dot. wyszukanych grup (rok założenia, liczba członków), ocena poziomu aktywności członków, a także tematyka zamieszczanych postów pozwoliły na wybór 90 grup o największym natężeniu aktywności, mieszczących się w wybranej tematyce. Grupy następnie zostały poddane obserwacji biernej, a w kolejnym etapie obserwacji czynnej polegającej na stymulowaniu dyskusji, a także komentowaniu wypowiedzi innych członków grup.

\section{WYNIKI BADAŃ}

Analiza grup społecznościowych działających w cyberprzestrzeni z perspektywy pięciu elementów/kryteriów obserwacji (organizacja czasu i przestrzeni, obiekty, aktorzy społeczni, interakcje, wydarzenia) umożliwiła dokonanie pogłębionej ich charakterystyki (tabela 3).

Tabela 3. Charakterystyka grup wirtualnych działających w ramach sharing economy

\begin{tabular}{|c|l|l|}
\hline Lp. & $\begin{array}{c}\text { Elementy/kryteria } \\
\text { obserwacji }\end{array}$ & \multicolumn{1}{|c|}{$\begin{array}{c}\text { Charakterystyka obserwowanych grup wirtualnych działających } \\
\text { w ramach sharing economy }\end{array}$} \\
\hline 1. & $\begin{array}{l}\text { Organizacja czasu } \\
\text { i przestrzeni }\end{array}$ & $\begin{array}{l}\text { Czym charakteryzuje się sposób organizacji spotkań z perspektywy ich czasu } \\
\text { i przestrzeni? } \\
\text { Członkowie obserwowanych grup wirtualnych spotykają się w cyberprze- } \\
\text { strzeni, możliwe jest umieszczanie postów oraz komentowanie wypowiedzi } \\
\text { innych osób w dogodnym czasie. }\end{array}$ \\
\hline 2. & Obiekty & $\begin{array}{l}\text { Jaka jest lokalizacja i dostępność obiektów - przestrzeni spotkań? } \\
\text { Grupy wirtualne funkcjonujące w ramach takich serwisów społecznościowych } \\
\text { jak Facebook, Instagram itp., skupiające osoby, których łączą wspólne zainte- } \\
\text { resowania, pasje, reprezentowane w danej dziedzinie poglądy (np. ochrona } \\
\text { środowiska), względy ekonomiczne. } \\
\text { W świecie wirtualnym występują tu dwie kategorie przestrzeni: przestrzeń } \\
\text { publiczna dostępna dla każdego użytkownika platformy społecznościowej } \\
\text { oraz prywatna - wymagana akceptacja administratora, w obu przypadkach } \\
\text { przeważnie konieczna jest akceptacja regulaminu grupy. } \\
\text { W związku z realizacją założonych celów członkowie wybranych grup spo- } \\
\text { tykają się również w świecie realnym - np. wymiana dóbr, oddanie rzeczy za } \\
\text { opłatą, wspólne korzystanie lub użyczanie aktywów trwałych innym grupowi- } \\
\text { czom. Wówczas dostępność przestrzeni i sposobu jej użytkowania regulowa- } \\
\text { na bieżącymi ustaleniami obu stron transakcji. }\end{array}$ \\
\hline
\end{tabular}




\begin{tabular}{|c|c|c|}
\hline 3. & Aktorzy społeczni & $\begin{array}{l}\text { Jakie unikatowe cechy można przypisać obserwowanej społeczności jako ca- } \\
\text { łości? Co odróżnia badaną społeczność od innych społeczności tego typu? } \\
\text { Członkowie wybranych, poddanych badaniu, grup wirtualnych to w przewa- } \\
\text { rzającej większości osoby młode w przedziale wiekowym 18-35 lat, mający } \\
\text { wspólne zainteresowania i pasje, zaangażowani, otwarci na innych, o zdecy- } \\
\text { dowanych przekonaniach, inteligentni, chcący się stale rozwijać i dokształcać, } \\
\text { charakteryzujący się bardzo szeroką, a w wielu przypadkach wręcz unikato- } \\
\text { wą wiedzą w danym obszarze (np. pielęgnacja roślin, włosów, decoupage itp.) } \\
\text { i chętnie się nią dzielący, przedsiębiorczy, poszukujący okazji, społecznicy - } \\
\text { żywo angażujący się w życie danej społeczności. } \\
\text { Podstawową cechą odróżniającą członków tych społeczności tych grup z pew- } \\
\text { nością jest zaangażowanie w realizowany cel. }\end{array}$ \\
\hline 4. & Interakcje & $\begin{array}{l}\text { Jak działania i zachowania członków społeczności wpływają na rozwój spo- } \\
\text { łeczności i jej otoczenia w cyberprzestrzeni, ale również w świecie realnym? } \\
\text { Specyfika obszaru, w którym działają grupy wymusza dość wysoki poziom } \\
\text { interakcji między jej członkami w świecie wirtualnym, wysoki poziom aktyw- } \\
\text { ności w ramach grupy, relatywnie częste spotkania w świecie realnym w celu } \\
\text { realizacji założeń statutowych grupy. }\end{array}$ \\
\hline 5. & Wydarzenia & $\begin{array}{l}\text { Czy wydarzenia wpływają pozytywnie czy negatywnie na rozwój samej spo- } \\
\text { łeczności w cyberprzestrzeni oraz czy mają wpływ na zmiany dokonywane } \\
\text { w przestrzeni realnej? } \\
\text { Wydarzenia odbywające się w cyberprzestrzeni zazwyczaj mają charakter } \\
\text { wymiany poglądów, opinii czy wiedzy. Mają więc pozytywny wpływ na człon- } \\
\text { ków danej społeczności. } \\
\text { Spotkania w świecie realnym mogą przynosić korzyści obu stronom wymiany, } \\
\text { mogą również wpływać na rozwój lokalnej społeczności, czy korzystne prze- } \\
\text { miany w obszarze infrastrukturalnym. }\end{array}$ \\
\hline
\end{tabular}

Źródło: opracowanie własne

Zastosowanie w badaniach zarówno obserwacji biernej, jak również obserwacji czynnej polegającej na stymulowaniu aktywności członków grup umożliwiło identyfikację tematów poruszanych w dyskusjach, charakteru podejmowanych aktywności, przedmiotu (rzeczy, informacje, usługi) wymiany, charakteru wymiany (for profit, nonprofit). Zebrany materiał badawczy pozwolił na wyszczególnienie typowych cech charakterystycznych dla poszczególnych modeli biznesu oraz ich klasyfikację według przyjętych kryteriów.

W związku z powyższym można powiedzieć, że grupy internetowe działające w obszarze sharing economy wyróżniają się pewnymi wspólnymi cechami:

- są przestrzeniami publicznymi lub prywatnymi,

- funkcjonują w ramach określonego serwisu społecznościowego,

- tworzone są w określonym celu,

- dysponują określonym regulaminem postępowania, który musi zostać zaakceptowany i przestrzegany przez wszystkich jej członków,

- zarządzane są przez administratora, który dba o przestrzeganie regulaminu grupy i stosuje odpowiednie sankcje w przypadku niestosowania się do niego,

- ich członkowie nie muszą wnosić żadnych opłat za możliwość podejmowania działań w tej przestrzeni,

- umożliwiają komunikację, wymianę informacji, dóbr i usług zarówno między osobami prywatnymi (P2P), przedsiębiorcami i osobami prywatnymi (B2P), między różnymi przedsiębiorcami (B2B), jak również między osobami prywatnymi i przedsiębiorcami (P2B), 
- aktywność podejmowana w ramach grupy może mieć charakter zarobkowy (for profit), jak również non profit.

Przeprowadzone badania empiryczne pozwoliły również na podział obserwowanych grup wirtualnych na cztery główne kategorie. Podział ten zgodny jest z klasyfikacją modeli biznesu sharing economy ze względu na obszar współdzielenia (tabela 4).

Tabela 4. Klasyfikacja modeli biznesu sharing economy wg obszarów współdzielenia

\begin{tabular}{|l|l|l|l|}
\hline Lp. & Obszar współdzielenia & $\begin{array}{l}\text { Przykładowe platformy } \\
\text { internetowe }\end{array}$ & $\begin{array}{l}\text { Przykładowe grupy wirtualne działające } \\
\text { w ramach serwisu społecznościowego }\end{array}$ \\
\hline 1. & Recyrkulacja towarów & eBay & $\begin{array}{l}\text { Kraków/Nowa Huta się dzieli/Is Sharing } \\
\text { Oddam za darmo, wymienię, pomogę } \\
\text { Rośliny - zamienię - oddam - Kraków } \\
\text { Mysie, Pysie i inne Stokrotki }\end{array}$ \\
\hline 2. & $\begin{array}{l}\text { Zwiększenie } \\
\text { wykorzystania aktywów } \\
\text { trwałych }\end{array}$ & $\begin{array}{l}\text { Uber, } \\
\text { Airbnb }\end{array}$ & $\begin{array}{l}\text { Couchsurfing Kraków } \\
\text { Kierowcy Uber \& Bolt \& Free Now Polska } \\
\text { Tarnów w Krakowie } \\
\text { Airbnb Polska }\end{array}$ \\
\hline 3. & Wymiana usług & BankCzasu.org & $\begin{array}{l}\text { Language Exchange Club Krakow } \\
\text { Tandem językowy } \\
\text { Duolingo } \\
\text { Wymiana umiejętności }\end{array}$ \\
\hline 4. & $\begin{array}{l}\text { Udostępnienie aktywów } \\
\text { wytwórczych }\end{array}$ & ShareSpace & $\begin{array}{l}\text { Wytwórnia Krakow } \\
\text { Made to Create - Creative Community } \\
\text { Saturday Art Classes } \\
\text { Kraków Miastem Startupów }\end{array}$ \\
\hline
\end{tabular}

Źródło: opracowanie własne

Analiza pozyskanego materiału badawczego pozwoliła również na zidentyfikowanie kluczowych charakterystyk różnicujących grupy działające w cyberprzestrzeni w ramach poszczególnych modeli biznesu, do których zostały przydzielone (tabela 5). Podstawowe elementy różnicujące poszczególne modele to: poza komunikacją via grupa internetowa również spotkania w świecie realnym lub online (np. z wykorzystaniem takich narzędzi jak Z00M, Messenger, MS Teams, Skype itp.), przedmiot wymiany, forma płatności, waluta, charakter non profit lub for profit.

Tabela 5. Charakterystyka modeli biznesu sharing economy wg obszarów współdzielenia

\begin{tabular}{|c|l|l|l|}
\hline Lp. & $\begin{array}{c}\text { Obszar } \\
\text { współdzielenia }\end{array}$ & $\begin{array}{c}\text { Przedmiot wymiany } \\
\text { w ramach grup } \\
\text { internetowych }\end{array}$ & \multicolumn{1}{c|}{ Charakterystyczne cechy } \\
\hline 1. & $\begin{array}{l}\text { Recyrkulacja } \\
\text { towarów }\end{array}$ & $\begin{array}{l}\text { aukcje internetowe, wymiana } \\
\text { rzeczy - zabawek, książek, } \\
\text { odzieży, sprzętu sportowego, } \\
\text { roślin, żywności }\end{array}$ & $\begin{array}{l}\text { komunikacja w ramach grupy internetowej, ale } \\
\text { również spotkania w świecie realnym związane } \\
\text { z fizyczną wymianą towarów, wymiana barterowa, } \\
\text { oddanie za darmo lub za opłata, przeważa charakter } \\
\text { non profit, skala działania lokalna, regionalna, krajo- } \\
\text { wa, międzynarodowa (poczta, kurier) }\end{array}$ \\
\hline 2. & $\begin{array}{l}\text { Zwiększenie } \\
\text { wykorzystania } \\
\text { aktywów } \\
\text { trwałych }\end{array}$ & $\begin{array}{l}\text { wynajem pokoi, odpłatne } \\
\text { użyczenie sprzętu domowego } \\
\text { użytku, wynajem pojazdów, } \\
\text { współdzielenie kosztów prze- } \\
\text { jazdu }\end{array}$ & $\begin{array}{l}\text { komunikacja w ramach grupy internetowej, ale } \\
\text { również spotkania w świecie realnym związane } \\
\text { z fizycznym użyczeniem dobra trwałego użytku, za } \\
\text { opłatą, wspólnego użytkowania dobra i współdzie- } \\
\text { lenia kosztów, charakter non profit lub ukierunko- } \\
\text { wany na zysk, skala działania lokalna, regionalna, } \\
\text { krajowa, międzynarodowa }\end{array}$ \\
\hline
\end{tabular}




\begin{tabular}{|c|c|c|c|}
\hline 3. & Wymiana usług & $\begin{array}{l}\text { banki czasu / wymiana umie- } \\
\text { jętności i wiedzy - nauka ję- } \\
\text { zyków obcych, gry na instru- } \\
\text { mentach, szycia, decoupage } \\
\text { i innych umiejętności i wie- } \\
\text { dzy, doradztwo podatkowe }\end{array}$ & $\begin{array}{l}\text { komunikacja w ramach grupy internetowej, ale } \\
\text { również spotkania online bądź w świecie realnym } \\
\text { związane z dzieleniem się wiedzą, umiejętnościami, } \\
\text { walutą jest tu czas, charakter non profit, lokalna ska- } \\
\text { la działania, regionalna, krajowa, międzynarodowa }\end{array}$ \\
\hline 4. & $\begin{array}{l}\text { Udostępnienie } \\
\text { aktywów } \\
\text { wytwórczych }\end{array}$ & $\begin{array}{l}\text { udostępnianie narzędzi } \\
\text { i przestrzeni do pracy - co- } \\
\text { working }\end{array}$ & $\begin{array}{l}\text { komunikacja w ramach grupy internetowej, ale } \\
\text { również spotkania w świecie realnym związane } \\
\text { z udostępnianiem narzędzi i przestrzeni do pracy, } \\
\text { za opłatą, działalność ukierunkowana na zysk, lo- } \\
\text { kalna skala działania }\end{array}$ \\
\hline
\end{tabular}

Źródło: opracowanie własne

\section{PODSUMOWANIE}

Modele biznesu związane z ekonomią współdzielenia stanowią szczególną odmianę modeli, których działanie oparte jest zwykle o platformy internetowe wyposażone w narzędzia wspierania relacji między partnerami. Co ciekawe, grupy internetowe tworzone w ramach platform (serwisów społecznościowych), dedykowanych zwykłej wymianie informacji, mogą być również wykorzystywane przez użytkowników do współdziałania w celu realizacji wartości uznawanych za konstytutywne dla ekonomii współdzielenia.

W oparciu o analizę literatury przedmiotu oraz badania wstępne postawiono tezę, którą następnie potwierdzono w toku badań empirycznych (obserwacja bierna i obserwacja uczestnicząca ukryta). Wirtualne grupy pełniąc podobne funkcje jak platformy internetowe sharing economy działają w oparciu o określone modele biznesowe, z tą różnicą, że nie pobierają opłat za dostęp i umożliwianie tworzenia się relacji między partnerami transakcji. Badania umożliwiły ponadto identyfikację kluczowych cech modeli biznesu sharing economy grup działających w cyberprzestrzeni. Z pewnością modele te różnicowane mogą być ze względu na obszar współdzielenia (recyrkulacja towarów, zwiększenie wykorzystania aktywów trwałych, wymiana usług oraz udostępnienie aktywów wytwórczych), orientację rynkową (non profit, for profit), skalę działania (lokalna, regionalna, krajowa, międzynarodowa), występowanie spotkań w świecie realnym lub ich brak, formę wymiany i płatności (barter, czas, pieniądz), relacje między podmiotami wymiany (P2P, B2P, B2B, P2B).

Należy tu nadmienić, iż w związku z faktem, iż badania prowadzone były w okresie pandemii COVID-19 zauważono interesujące tendencje. Otóż prowadzone obserwacje wykazały istotne zmiany w charakterze aktywności internautów - np. w grupach dotyczących transportu - wygaśnięcie aktywności, w grupach dotyczących turystyki - zmiana formatu na reklamowy, w grupach dotyczących wymiany dóbr, czasu i umiejętności - istotny wzrost aktywności, w pewnych sytuacjach przechodzący w poszukiwanie nowych form zarobkowania.

\section{Literatura \\ References}

Babbie, E. (2003). Badania społeczne w praktyce. Warszawa: Wydawnictwo Naukowe PWN.

Chomczyński, P. (2006). Wybrane problemy etyczne w badaniach. Obserwacja uczestnicząca ukryta. Przegląd Socjologii Jakościowej, 2(1), 68-87. 
Ciesielska, M., Wolanik Boström, K., Öhlander, M. (2012). Obserwacja. W: D. Jemielniak (red.), Badania jakościowe. Metody i narzędzia. 2, 41-67.

Cichocki, P., Jędrkiewicz, T., Zydel, R. (2012). Etnografia wirtualna. W: D. Jemielniak (red.), Badania jakościowe. Metody i narzędzia. 2, 204-220.

Combe, C. (2006). Introduction to e-business, managementand strategy. Amsterdam i in. ButterworthHeinemann.

Doktór, K. (1964). Przedsiębiorstwo przemysłowe. Studium socjologiczne Zakładów Przemysłu Metalowego „Cegielski”. Warszawa: Książka i Wiedza.

Falencikowski T. (2012). Strategia a model biznesu - podobieństwa i różnice. Prace Naukowe Wydawnictwa Uniwersytetu Ekonomicznego we Wrocławiu, 260, 80-93.

Farrington, A., Robinson, W.P. (1999). Homelessness and strategies of identity maintenance. A participant observation study. Journal of Community \& Applied Social Psychology, 9(3), 175-194.

Gajdzik, B., Grabowska, S. (2018). Modele biznesowe w przedsiębiorstwach 4.0 - próba identyfikacji założeń użytych do wyznaczenia nowych modeli biznesu. Zarządzanie Przedsiębiorstwem, 21(3), 2-8. doi: 10.25961/ent.manag.21.03.01.

Hammersley, M., Atkinson, P. (2000). Metody badań terenowych. Poznań: Wydawnictwo Zysk i S-ka. Hausner, J., Zmyślony, M. (2015). FIRMA-IDEA - nowe podejście do wartości w biznesie. Sopot: Agencja Artystyczna GAP. Pozyskano z http://www.kulturairozwoj.pl/doki/ spis/KIR-0/kir_0-06.pdf (dostęp 14.03.2021).

Johnson, M. (2010). Seizing the white space. Business model innovation for growth and renewal. Boston: Harvard Business School Publishing.

Johnson, M. (2013). Rozwój przez innowacje w modelu biznesowym. Rozmawiał W. Jankowski Harvard Business Review Polska.

Konecki, K.T. (2000). Studia z metodologii badań jakościowych. Teoria ugruntowana. Warszawa: Wydawnictwo Naukowe PWN.

Nojszewski, D. (2006). Przegląd modeli e-biznesowych. 1. E-mentor, 5. Pozyskano z http://www.e-mentor.edu.pl/artykul/index/numer/17/id/375 (dostęp 18.03.2021).

Osterwalder, A., Pigmeur, Y. (2012). Tworzenie modeli biznesowych, Gliwice: Onepress.

Płaziak, M. (2020). Obserwacja uczestnicząca w badaniach internetowych dotyczących wirtualnych społeczności lokalnych. W: K. Mazurek-Łopacińska, M. Sobocińska (red.), Badania marketingowe w gospodarce cyfrowej. Wrocław: Wydawnictwo Uniwersytetu Ekonomicznego we Wrocławiu, 223-234.

Płaziak, M., Szymańska, A.I. (2019). Preferencje młodych użytkowników przestrzeni miejskiej Krakowa w zakresie wyboru alternatywnych form transportu. Prace Komisji Geografii Przemysłu Polskiego Towarzystwa Geograficznego, 33(3), 36-57. doi: $10.24917 / 20801653.333 .3$

Poniatowska-Jaksch, M. (2013). Sieciowe modele biznesu. W: M. Duczkowska-Piasecka (red.), Model biznesu. Nowe myślenie strategiczne, Warszawa: Difin.

Poniatowska-Jaksch, M. (2016). Modele biznesu w sharing economy. W: M. Poniatowska-Jaksch, R. Sobiecki (red.), Sharing economy (gospodarka współdzielenia), Warszawa: Oficyna Wydawnicza SGH.

Prus, R., Grills, S. (2003). The Deviant Mystique. Involvements, Realities and Regulation. Westport, CT; London: Preager.

PwC Polska. (2016). (Współ)dziel i rzq̨dź! Twój nowy model biznesowy jeszcze nie istnieje. Pozyskano z https://www.pwc.pl/pl/pdf/ekonomia-wspoldzielenia-1-raport-pwc.pdf (dostęp 18.03.2021).

Rude, L. (2016). 4 Keys to a Successful Sharing Economy Business Model. Pozyskano z https:// www.text100.com/articles/technology/sucessful-sharing-economy-business-model/ (dostęp 17.03.2016).

Shaughnessy, J.J., Zechmeister, E., Zechmeister, J.S. (2002). Metody badawcze $w$ psychologii. Gdańsk: Gdańskie Wydawnictwo Psychologiczne.

Schor, J. (2014). Debating the Sharing Economy, Great Transition Initiative. Toward a Transformative Vision and Praxis. Pozyskano z http://www.tellus.org/pub/Schor_Debating_the_ Sharing_Economy.pdf (dostęp 18.03.2021). 
Szymańska, A.I. (2017). Sharing economy jako nowy trend w zachowaniach konsumentów. Marketing i Rynek, 23(9), 417-425.

Szymańska, A.I. (2018). Zastosowanie modelowania ścieżkowego w badaniu konsumpcji kolaboratywnej. Prace Naukowe Uniwersytetu Ekonomicznego we Wrocławiu, 525, 68-82. doi: 10.15611/pn.2018.525.06.

Szymańska, A.I. (2020). Focus Group Interviews Employed in the Research Analysing Young Adults' Behaviour on the Market of Alternative Means of City Transport. Prace Komisji Geografii Przemysłu Polskiego Towarzystwa Geograficznego, 34(3), 84-95. doi: https://doi. org/10.24917/20801653.343.6.

Weill, P., Vitale, M.R. (2001). Place to space, migrating to ebusiness models. Boston, MA: Harvard Business School Press.

Anna Irena Szymańska: dr, adiunkt, Uniwersytet Ekonomiczny w Krakowie, Instytut Zarządzania, Katedra Handlu i Instytucji Rynkowych. Zainteresowania badawcze autorki oscylują wokół problematyki potrzeb, preferencji i zachowań rynkowych konsumentów, konsumpcji kolaboratywnej i innych form alternatywnego dostępu do dóbr, nowych trendów w konsumpcji oraz ich implikacji dla strategii biznesowych przedsiębiorstw. Ponadto zajmuje się problematyką przedsiębiorczości i innowacyjności przedsiębiorstw ze szczególnym uwzględnieniem sektora MŚP oraz gospodarki cyrkularnej.

Anna Irena Szymańska: Ph.D., assistant professor, Cracow University of Economics, Institute of Management, Department of Trade and Market Institutions. Her research interests are related to the issue of consumer needs, preferences and market behaviour, collaborative consumption and other forms of access-based consumption, new trends in consumption and their implications for business strategies, as well as issues in the area of entrepreneurship and innovation with particular emphasis on the SME sector and circular economy.

ORCID: https://orcid.org/0000-0002-1973-2696

\section{Adres/address:}

Uniwersytet Ekonomiczny w Krakowie

Instytut Zarządzania

Katedra Handlu i Instytucji Rynkowych

ul. Rakowicka 27

31-510 Kraków

e-mail: szymanska@uek.krakow.pl 